\title{
HUMAN IMMUNODEFICIENCY VIRUS (HIV) PREVENTION PROGRAM AMONG MEN WHO HAVE SEX WITH MEN (MSM) IN SEMARANG CITY
}

\author{
Program Pencegahan HIV pada Lelaki Seks dengan Lelaki (LSL) di Kota Semarang
}

\author{
*Benita Noffritasari', Zahroh Shaluhiyah'1, M. Sakundarno Adi \\ ${ }^{1}$ Faculty of Public Health, Diponegoro University, Indonesia \\ *Correspondence: noffritasari@gmail.com
}

\begin{abstract}
Background: The prevalence of Human Immunodeficiency Virus (HIV) among Men who have Sex with Men (MSM) in Indonesia continues to increase. The HIV cases among MSM in Semarang increased by 43 cases in 2013 to 147 cases in 2017. The prevalence of syphilis among MSM increased by $5.20 \%$ in 2011 to $11.38 \%$ in 2015. The use of condoms among MSM does not reach 50\%. The Prevention Program of Sexually Transmitted Disease of HIV or Pencegahan HIV melalui Transmisi Seksual (PMTS) that focuses on sexual transmission risk factors did not provide optimal results.

Aim: This study aimed to analyze aspects affecting the PMTS Program on MSM in Semarang City, including standard and objectives, resources, inter-organizational communication and enforcement activities, characteristics of the implementing agencies, economic, social, and political conditions, and the disposition of implementors.

Method: This study was a descriptive study using a qualitative approach. Primary data were obtained through indepth interviews with 14 informants, while secondary data were obtained from observation and document analysis. The data were analyzed using content analysis. The research was conducted from July to October 2019 in Semarang City.

Results: The implemetation of the PMTS Program among MSM has some gaps. For example, these included (1) unclear standards of PMTS Program, (2) limited funding and infrastructures, (3) lack of communication, (4) stigma and discrimination at the stakeholder level, implementing agencies level, and community level.

Conclusion: The implementation of PMTS Program among MSM has not worked appropriately. Eliminating stigma and discrimination against MSM needs to be taken into account. All health workers in primary healthcare centers must be introduced to the diminish of stigma and discrimination against MSM. Communication and coordination as well as resources among the program implementers have to be more well-established.
\end{abstract}

Keywords: Human Immunodeficiency Virus, Men who have Sex with Men, prevention program.

\section{ABSTRAK}

Latar Belakang: Prevalensi kasus Human Immunodeficiency Virus (HIV) pada Lelaki Seks dengan Lelaki (LSL) di Indonesia terus meningkat. Penemuan kasus HIV pada LSL di Kota Semarang juga mengalami peningkatan dari 43 kasus pada tahun 2013, menjadi 147 kasus pada 2017. Prevalensi sifilis pada LSL meningkat dari 5,20\% pada tahun 2011 menjadi 11,38\% pada tahun 2015. Penggunaan kondom di kalangan LSL, tidak mencapai 50\%. Program Pencegahan HIV Melalui Transmisi Seksual (PMTS) sebagai upaya pencegahan HIV AIDS dengan faktor risiko penularan melalui hubungan seksual, dirasa belum berjalan optimal.

Tujuan: Penelitian ini bertujuan untuk mengetahui bagaimana implementasi Program PMTS pada LSL di Kota Semarang, ditinjau dari faktor tujuan dan standar, sumberdaya, komunikasi antar organisasi dan kegiatan pelaksanaan, karakteristik badan pelaksana, lingkungan ekonomi, politik dan sosial, serta disposisi pelaksana.

Method: Penelitian ini adalah penelitian deskriptif dengan pendekatan kualitatif. Pengumpulan data primer dengan cara indepth interview terhadap 14 orang informan, sedangkan data sekunder diperoleh dari pengamatan dan telaah dokumen. Analisis data dilakukan dengan content analysis. Penelitian dilaksanakan di Kota Semarang selama bulan Juli hingga Oktober 2019. 
Hasil: Terdapat beberapa kesenjangan dalam pelaksanaan Program PMTS pada LSL. Contoh kesenjangan tersebut meliputi (1) sasaran Program PMTS yang kurang jelas, (2) kurangnya komunikasi, (3) keterbatasan sumber dana dan sarana prasarana (4) stigma dan diskriminasi terhadap LSL, baik di tingkat pemangku kepentingan, pelaksana program maupun masyarakat.

Kesimpulan: Implementasi program PMTS pada LSL belum berjalan dengan baik. Upaya penghapusan stigma dan diskriminasi terhadap LSL perlu terus diupayakan. Semua petugas kesehatan di Puskesmas harus dikenalkan tentang penghapusan stigma dan diskriminasi terhadap LSL. Komunikasi dan koordinasi serta sumber daya di antara pelaksana program PMTS perlu terus ditingkatkan.

Kata kunci: Human Immunodeficiency Virus, Lelaki Seks dengan Lelaki, program pencegahan.

\section{INTRODUCTION}

HIV/AIDS continues to be a concern across countries worldwide. Data from the Joint United Nations Programme on HIV/AIDS (2018) mentioned that until the end of 2017, around 36.9 million people in the world lived with HIV/AIDS, and 1.8 million additional cases suffered from HIV/AIDS.

The HIV epidemic in Indonesia is still concentrated among specific key populations (direct and indirect female sex workers, people who inject drugs, men who have sex with men, transgendered people, and high risk men) except in Papua, experiencing a low level of generalized epidemic. The nationally estimated prevalence among the adult population was $0.33 \%$. Data released by the Ministry of Health (2017a) showed at the end of 2017, as many as 280,623 people lived with HIV and 102,667 got AIDS in Indonesia. Sexual risk behaviors among heterosexuals became the most tendentious HIV transmission risks at $69.6 \%$, the use of unsterilized needles decreased by $9.1 \%$ and the number of homosexuals was $5.7 \%$ (Indonesian Ministry of Health, 2017b).

In the last decades, the trends of HIV prevalence in Indonesia has shifted. New HIV cases through contact with needles are now shifting to transmit through Female Sex Workers (FSW), and now HIV is transmitted through Men who Sex with Men (MSM) (Indonesian Ministry of Health, 2017b). From 2007 to 2015, the HIV prevalence among MSM increased by $5.35 \%$ to $25.80 \%$. The estimated number of MSM was $1.1 \%$ out of all male adults aged between 15 and 49 years in Indonesia. The risk factors of HIV transmission among MSM were 28 times greater than among other populations, and this prevalence of HIV continues to increase in the following years (Indonesian Ministry of Health, 2017a; Joint United Nations Programme on HIV/AIDS, 2018a).

The Prevention Program of Sexually Transmitted Disease of HIV or Pencegahan HIV melalui Transmisi Seksual (PMTS) is a national HIV and AIDS prevention program focusing on risk factors through sexual transmission, whether it is a heterosexual or homosexual transmission. The PMTS Program has been developed since 2008 to respond to the increasing HIV and AIDS cases through sexual transmission (National AIDS Coalition, 2010). The PMTS Program is the implementation of the Regulation of the Indonesian Minister of Health Number 21 of 2003 concerning HIV and AIDS Prevention, and this regulation was stipulated too in the Regulation of Semarang City Number 4 of 2013 concerning HIV and AIDS.

Without any policy implementation, programs will only become a pile of documents. To implement a public policy, there are two steps taken, such as implementing the policy directly in a program or formulating derivative policies 
from the public policy (Nugroho, 2011). The policy implementation of PMTS results in the PMTS Program.

Although PMTS Program has been implemented for years, it does not optimally cope with HIV and AIDS cases in Indonesia, especially in the key population of MSM (Hubaybah and Fadzlul, 2014; Puspitaningtyas et al., 2014; Rokhmah and Khoiron, 2015). The prevalence of Sexually Transmitted Infections (STI), especially syphilis among MSM, gets increasing. Men who get STI may be at an increased risk of HIV infections (Pathela et al., 2013; Peterman et al., 2014). Studies demonstrated that a recent syphilis infection can increase the risk of HIV seroconversion by 2.6 times (Solomon et al., 2014). The Integrated Biological and Behavioral Survey (IBBS) in 2007, 2011, and 2015 described an increase in the prevalence of syphilis among MSM of $4.33 \%, 9.29 \%$, to $15.71 \%$. The survey in 2011 also exhibits that the latest consistency of condom use for anal sex among MSM in Surabaya City was at $75.9 \%$ but decreased by $53 \%$ according to Quick Behavioral Survey in 2013. The same consistency was also found in the 2015 Integrated Biological and Behavioral Survey, which discovered that the use of condoms among MSM was still low (Indonesian Ministry of Health, 2015).

Ranked as the second-highest HIV cases in Central Java, Semarang City found 534 new HIV cases and 33 AIDS cases in 2017 (Semarang AIDS Coalition, 2017). The number of HIV cases among MSM in Semarang increased by 43 cases in 2007 up to 147 cases in 2017. The prevalence of sexually transmitted infections, syphilis among MSM, increased by $5.20 \%$ in 2011 up to $11.38 \%$ in 2015 . Besides, the use of condoms among MSM in Semarang City did not reach 50\% (Indonesian Ministry of Health, 2015).
Many factors affect the success of public policy implementation, especially for overcoming HIV and AIDS (Dasgupta et al., 2016; McRobie et al., 2017; Philbin et al., 2018). The analysis of the integration of HIV/AIDS program with national health system in Indonesia showed that the program implementation failed not because of regulation and policy formulation, but poor policy implementation (Center for Health Policy and Management of Gajah Mada University, 2015). Van Meter and Van Horn in the public policy implementation theory asserted that some factors influencing on the success of public policy implementation involve policy objective and standard, inter-organizational communication and enforcement activities, characteristics of implementing agencies, economic, social, and political conditions, and disposition of implementors (Van Meter and Van Horn, 1975).

This study aimed to analize the implementation of the PMTS Program among the key population of MSM in Semarang City. This study looked at several factors, such as policy objective and standard, inter-organizational communication and enforcement activities, characteristics of implementing agencies, economic, social, and political conditions, and disposition of implementors. This study was expected to provide a recommendation for future improvement of the HIV/AIDS prevention program, especially among MSM.

\section{METHOD}

This study utilized an explorativedescriptive design with a qualitative method. It was conducted in Semarang City from August to October 2019 by deploying in-depth interviews, observation, and document review. An in-depth 
interview was done by using an interview guide book to investigate the implementation of the PMTS Program among MSM. This study explored some factors that affect the program implementation, such as policy objective and standard, inter-organizational communication and enforcement activities, characteristics of implementing agencies, economic, social, and political conditions, and disposition of implementors.

This study involved 3 key informants which were selected with a purposive sampling. The main informants were the ones who manage the PMTS Program, such as the Semarang AIDS Coalition, District Health Office, and the Indonesian Family Planning Association. While the triangulation informants were those who manage the PMTS Program, such as6 primary healthcare centers and 5 patients who are MSM and have accessed HIV services in the primary healthcare centers. All six primary healthcare centers were chosen because of the higher number of MSM visits compared to other primary healthcare centers in Semarang. MSM patients as informants were obtained by primary helathcare centers officers. They contacted the MSM patients who accessed the HIV services and were willing to take a part in the study.

Face to face interview with each informant was scheduled at their convenient time and places. Prior to the interviews, informants were informed about the aim of the study and the mechanism of their voluntary participation. The interview took approximately 60 minutes used a tape recorder. To inform the informants about the research, a written information sheet about the aim and nature of the research was given before the informants were asked to sign a consent form. This study obtained the ethics approval from the Health Research
Ethics Committee, Faculty of Public Health, Diponegoro University, Semarang, Indonesia (Ref. No.: 187/EA/KEPK$\mathrm{FKM} / 2019$ ).

Data obtained through in-depth interviews, observation, and document analysis were analyzed by using Miles and Huberman Models (Sugiyono, 2015). First, the data were summarized as necessary according to the main objectives of this study. Second, the data were presented in narration. Third, the researchers made conclusions based on valid and consistent evidences. The validity of the data was obtained by triangulating sources from the triangulation informants. The researchers further confirmed some information discrepancies to different informants. They considered consistent answers from each informant to draw conclusions (Sugiyono, 2015).

\section{RESULTS AND DISCUSSION}

The PMTS Program among MSM in Semarang City applied four activities, such as improving stakeholders' participation, intervening behavioral changes, managing supplies of condoms and lubricants, and providing services for HIV and sexually transmitted infections. All these activities support each other to identify behavioral changes among the key population. The implementation of the PMTS Program among MSM in Semarang City was sought from factors affecting the success of the implementation.

\section{Program Objective and Standard}

Policy implementation is a process to change policy objectives and target into real actions. Objective and standard explain further goals to achieve through policy implementation and to find proper achievement assessment. Policy objectives and standards have to be clear 
and measurable, and thus they can be executed into actions. Understanding policy objectives and the standard is prominent in policy implementation. The policy implementation might fail when the implementers do not optimally understand the policy objectives and standards (Van Meter and Van Horn, 1975).

As the implementers of the PMTS Program, the main informants from the Semarang AIDS Coalition, District Health Office, primary healthcare centers, and non-profit organizations have understood the objectives of the PMTS Program, as well as the PMTS Program for MSM. They mentioned that the objectives of the PMTS Program were to prevent HIV infection through sexual intercourse by using four activities. These include improving stakeholders' participation, intervening behavioral changes, managing condom supplies as well as services for HIV and sexually transmitted infections. Besides, each of the main informants understood their roles and functions according to these four activities.

"PMTS Program aims to prevent HIV through sexual intercourse. The first program was initiated for the key population, actually for all key populations. The PMTS Program consists of four activities, such as improving stakeholders' participation, intervening stakeholders, managing condom supplies and services, especially for HIV and AIDS... All of them have been implemented. We gathered stakeholders, non-profit organization. Also, we provide condoms and services for HIV and sexually transmitted infections..." (Informant from

Semarang AIDS Coalition).

The informants statement were suitable for document review in Chapter 13 of Regulations of Indonesian Ministry of Health No. 21 of 2013 about HIV and AIDS management, as well as PMTS Guidelines published by the National AIDS Coalition. The guidelines mention that PMTS aims to prevent individuals to get HIV and/or other sexually transmitted infections. The PMTS Program was conducted through four integrated activities, which include improving stakeholders' participation, intervening behavioral changes, managing medical supplies, preventing and controlling sexually transmitted infections (National AIDS Coalition, 2010; Indonesian Ministry of Health, 2013).

Policy standards implicitly or explicitly can be drawn upon the indicators as mentioned in the policy. These indicators are the real actions of policy objectives and standards. Policy indicators may come from policymakers' statements or criteria in documents, such as regulations or guidelines used to evaluate a policy (Van Meter and Van Horn, 1975).

Unlike the answers about policy objectives, the main informants gave different perspectives about the standard of PMTS Program among MSM. The main informants from Semarang AIDS Coalition stated that the standard of PMTS Program is the completion of those four activities. While the main informants from Non-Profit Organization said that the number of reached MSM is the standard of PMTS Program for MSM. In contrast, the Semarang District Health Office mentioned no target number of MSM to provide HIV testing services. This argument was in line with the main informants from primary healthcare centers. 
"There is no target number for PMTS Program. We normally use a fast-track target like $90 \%$ of HIV status was detected. Then, we breakdown the lists of people with HIV. We tested the key population. We target all patients who come will get served. In short, we never target the minimum number of patients in providing HIV services.." (Informant from District Health Office).

The document review showed that the indicators of the PMTS Program are different in measuring the implementation success among MSM. The National AIDS Coalition mentioned in the Guidelines for HIV and Sexually Transmitted Infection Program that there are some core indicators in monitoring and evaluating the program. These include the number of PMTS locus, the reachable number of key populations, the number of distributed condoms, and the number of key populations that participate in HIV screening and undergo HIV and sexually transmitted infection services (National AIDS Coalition, 2010).

The National Strategy and Action Plan from 2015 to 2019 determines indicators of the prevention program and behavioral changes of key populations. First, the achievement of peer education, information and education communication, and HIV prevention tools, such as condoms and lubricants based on the targeted MSM's needs was respectively $28 \%, 36 \%, 44 \%$, 52\%, and $60 \%$ between 2015 and 2019. Second, the target use of condoms for sexual intercourse once a week or in the last month among MSM from 2015 to 2019 was $64 \%, 68 \%, 72 \%$, $76 \%$, and $80 \%$ respectively. Third, the percentage of targeted key populations tested for HIV in the period of 2015 to 2019 amounted to $25 \%, 40 \%, 60 \%, 70 \%$, and $80 \%$ respectively (National AIDS Coalition, 2015).

Semarang Strategy and Action Plan in the period of 2016-2020 stated that the PMTS Program for high-risk population has several indicators. One of them is to provide counseling to high-risk populations (female sex workers, men who have sex with men, and Lesbian Gay Bisexual Transgender) with percentages of $40 \%$, $50 \%, 75 \%$ and $80 \%$ from 2017 to 2020 (Semarang AIDS Coalition, 2016).

Interview and review results of the guidelines explain that the program implementers have clearly understood the program objectives, but they have a different opinion about the program standard. A review of three PMTS program documents showed that the PMTS Program among MSM has not had a clear and consistent target. Each guideline has its indicator different from other documents. Unclear program target makes the main informants have a different understanding of the program target. All policy implementers have to comprehend what matters in the policy since they will be responsible for implementing it. Different understanding will lead to unachieved goals of the PMTS Program among MSM (Kadji, 2015). Policy failure was also found in Nigeria, where policymakers failed to clearly define the policy objectives, as well as had overambitious objectives that are difficult to achieve (Kamoru and Ahmed, 2016).

In overcoming such problems, Semarang AIDS Coalition has to participate actively as a coordinator for HIV prevention, who promotes the objectives and standards of the PMTS Program among MSM. They can gather individuals to inform about PMTS policy or 
program to all PMTS working groups in every coordination meeting which has regularly run for 6 months.

\section{Resources of PMTS Program}

According to Edward III in Widodo (2012), the success of policy implementation depends on resources. A program or policy will run well when human resources are available and competent, funding is adequate, and facilities and infrastructures are wellprovided. Human resources are one of the resources that have important functions in succeeding the policy implementation. Every process of policy implementation demands competent human resources that have the expertise required in the policy (Widodo, 2012).

Most of the main informants argued that the PMTS Program in Semarang has enough human resources. The number of human resources is considered sufficient in implementing all activities of the PMTS Program.

"The human resources for patient outreach come from the Indonesian Family Planning Association (PKBI). They are funded by the donors. The number of human resources for HIV healthcare service are just enough. I think there is no problem in Semarang in terms of human resources..." (Informant from Semarang AIDS Coalition).

Most of the main informants considered that the workers have enough competence. It is noticeable from their educational background, which most of them graduated from the Associate's Degree, Bachelors, and masters. A program for developing the workers' competency is conducted concurrently through training and On Job Training (OJT) by Semarang District Health Office.

"Now we have been developing
HIV services without certified
counselors, but Provider-
Initiated HIV Testing and
Counseling (PITC). Our
laboratorians have regular
refreshment meeting every two
years. We also conduct
workshops..." (Informant from
District Health Office).

The triangulation informants who accessed HIV services in primary healthcare centers stated that the health workers in the front office often put stigma and discrimination against them. The health workers tend to preach MSM about norms and morals, and thus these bother them.

"I still found stigma and
discrimination in the services
like they say "you shall repent
what you have done. Why do
you like men?" Some staffs talk
about it. It is bothering
somehow. The staffs basically
only need to explain about
health consequences and
treatments instead of norms,
religious norms, and morals.."
(Informant who acessed the
HIV service).

Despite that, finance also affects the effectiveness of program implementation. Limited funding will influence the success of the program implementation. The main informants from Semarang AIDS Coalition and Semarang District Health Office supposed that the funding was lacking. Grants were given to Semarang AIDS 
Coalition for conducting coordination meetings and meeting with working groups of PMTS. Meanwhile, the main informants form the Non-Profit Organization and primary healthcare centers argued that the grants were sufficient for implementing the PMTS Program among MSM in Semarang.

"Normatively, the grants are lacking , but we use it optimally. The amount of grants are allocated by the District Government and District Health Office. If there is funding efficiency, all Regional Working Units (SKPD) will receive less funding..." (Informant from Semarang AIDS Coalition).

The Semarang District Health Office obtains financial support from various sources, such as National Budget (APBN), Specific Allocation Fund (DAK) and Local Governmet Budget (APBD). Semarang District Health Office in 2018 collected Local Government Budget amounted to IDR 334,047,627,000.00. Compared to Semarang Local Government Budget amounted to IDR 3,513,753,947,218.00, the percentage of allocation funds given to the Semarang District Health Office was 9.51\%. They spend IDR 565,102,500.00 or $1.7 \%$ for HIV and AIDS Prevention Program. The allocation fund for HIV Prevention Program decreased by IDR $320,000,000.00$ in 2019 since the government focused on infrastructure development and made more efficiency of program funding.

Another financial problem is the financial allocation for the PMTS Program among MSM. The main informants stated that they were afraid to allocate certain budget for the PMTS Program among MSM.

\begin{abstract}
"We are not brave enough to propose activities for MSM. But, if we get funding from donors, we can target activities for MSM. The donors provide all since they prioritize them. However, we are fearful of using Local Government Budget to conduct activities for MSM..." (Informant from Semarang AIDS Coalition).
\end{abstract}

A program will not work well when there is no enough infrastructure and facilities. It is not enough to just have competent human resources and funding but supporting infrastructure and facilities. As a result, policy implementation will fail.

Regarding facilities and infrastructure, most of the main informants said that the availability of infrastructure and facilities for the PMTS Program among MSM in Semarang were considered adequate. However, based on the observation, four of six selected primary healthcare centers had no specific counseling room for HIV services. The counseling room is merged with other patient rooms. Such a room setting will make MSM uncomfortable when they consult the health workers.

In conclusion, problems found in terms of resources are that the health workers still put stigma and discriminate MSM, and the grants are still inadequate. Also, the health workers were afraid to allocate funds for PMTS Program among MSM, and the availability of infrastructure and facilities is still not good, especially the setting of the counseling room.

Viewed from the number and competency of the human resources in the primary healthcare centers, the health workers have a good educational background. Nevertheless, it does not 
guarantee that there will be no stigma and discrimination in healthcare services. In fact, not all health workers participate in HIV training, especially that talks about avoiding stigma and discrimination in healthcare services. There is only one team selected to represent in the HIV training, while patients who are MSM will meet with other health workers who might not get exposed to it.

These findings are different from what has been found among health workers in Malawi. The health workers have admitted that MSM have needs and equal rights to health access. They provide the best services because they realize their professional responsibility (Kapanda et al., 2019).

Moreover, inadequate availability of infrastructure and facilities, such as a counseling room that has not been specified, will hardly make MSM reveal their health status to the health workers. Therefore, the health workers cannot provide the best services matching to their health condition and needs (Philbin et al., 2018).

Financially, the Semarang AIDS Coalition and Semarang District Health Office received insufficient funding for PMTS Program and some other related activities, especially from the Local Government Budget. Apart from the funding efficiency by Semarang Regional Government, fear of proposing a certain financial plan for HIV Program among MSM made the funding mechanism worse. When it is impossible to exactly come up with the issue of MSM during the financial arrangement advocacy, this situation will affect the funding received.

The results also have the same ideas as a study conducted in Sorong District. The support of funding allocation for the HIV AIDS Prevention Program was still lacking since Sorong AIDS Coalition and Sorong District Health Office did not report the HIV AIDS prevention to the key policymakers, such as Agency for Regional Development (BAPPEDA) (Mahendradhata et al., 2015).

Good resources, e.g. human resources, funding, infrastructure, and facilities, will be significant for implementing a program well. The ideas are in line with a study about the integration of HIV/AIDS Prevention Program in a health system. They picked a case study of the PMTS Program among MSM in Denpasar. The lack of resources, specifically funding and human resources, affects the success of the integrated PMTS Program in Denpasar District (Nopiyani, Sari and Sutarsa, 2016).

\section{Interorganizational Communication and Activity Execution}

Implementing a program needs support and collaboration with other stakeholders. The success of program implementation depends on the institutional procedures and mechanism, whether top-level managers need to take over the implementation or not. Thus, their participation can control the implementation according to the objectives and standards (Subarsono, 2012).

Having discussed the clarity and consistency of communication, the main informants said that the information of the PMTS program has been spread in a fast, clear, and consistent way. All information refers to the Regulation of the Indonesian Ministry of Health Year 2013. It has been informed to the lowest personnel position, which is the key population of MSM. Based on the interview, the interorganizational communication process has run well. The organizations gather both offline and online in coordination meetings or telephone and social media such as Whatsapp. 
However, this study found that communication and coordination between the institutions were still lacking. Even though activity coordination was carried out routinely, not all stakeholders did not eagerly participate. Only Semarang AIDS Coalition and Semarang District Health Office took a part in the Program. Meanwhile, other institutions which are members of the PMTS working group were involved if a program relates to their duties and functions.

"The stake holders... It can be understood because it is not their main function, except for the District Health Office and the AIDS Coalition. While it is not the main roles of others institutions unless there are sex parties in which they contribute to combat. However, if the context is about HIV prevention, other PMTS working group members will not take a part" (Informant from Semarang AIDS Coalition).

The researchers also found a problem in terms of the supply management of condoms and lubricants. While Semarang AIDS Coalition mentioned that the distribution of condoms and gels have been distributed to primary healthcare centers, some of the primary healthcare centers collect condom supplies from National Family Planning Coordination Board (BKKBN) through maternal and child health program as well as family planning program. Furthermore, they reported that Semarang AIDS Coalition never distributes lubricants for PMTS Program. The main informant from Semarang District Health Office stated that the supply management of condoms and

lubricants was overtaken by Semarang AIDS Coalition.

"Since I motivate to use condoms, I will give MSM. However, they need lubricants. Unfortunately, we do not have it. The $B K K B N$ provide the condom supplies, while we do not have any lubricant supplies. We will give a condom that $B K K B N$ gives to us. I do not think we have some from Semarang AIDS Coalition. We only receive reagents perhaps from the District Health Office, or we never ask them for condom supplies..." (Informant from 5th Primary Healthcare Center).

The lack of communication and coordination in the program implementation impedes the success of the PMTS Program in Semarang. It also occurs in the implementation of the PMTS Program in Tanah Bambu District. The researchers, Juhairiyah and Lenie Marlinae, discovered that interorganizational coordination shortage resulted in an unwell-implemented PMTS Program, and thus the implementers could not reach the key population of MSM (Juhairiyah and Marlinae, 2016). The unavailability of condoms and lubricants in the primary healthcare centers matters because condoms and lubricants are away effective to prevent HIV among MSM (Haig et al., 2016; Johnson, Leary and Flores, 2018).

\section{Implementing Bodies' Characteristics}

Characteristics of implementing bodies include their bureaucrary structures, organizational norms, and pattrens of relationships that occur in 
bureaucracy. The characteristics of implementing bodies can be seen through whether or not they apply Standard Operating Procedures (SOP), task distribution mechanism, and supervision (Subarsono, 2012). These overall characteristics will impact the implementation of programs.

Speaking about SOP, the main informants from Semarang AIDS Coalition and Semarang District Health Office stated that they have already had SOP of PMTS Program, especially in the primary healthcare services. SOP is formulated by referring to the Regulation of the Indonesian Ministry of Health. All main informants from the primary healthcare centers also asserted that they have SOP of HIV services, including SOP of Voluntary Counselling and Testing (VCT), Prevention of Mother-To-Child Transmission (PMTCT) and sexually transmitted infections.

Standard Operating Procedures in the technical implementing bodies, e.g. primary healthcare centers, are crucial. The SOP is used to document how tasks are completed in the primary healthcare centers with the right guidelines. SOP also communicate clarity and easy access to services when patients use healthcare services. In the same way, the triangulation informants (MSM) thought that the primary healthcare centers already have clear and understandable patient flow.

Furthermore, the main informants from Semarang AIDS Coalition claimed that they have shared jobs with the District Health Office and Non-Profit Organization. The coordination meetings of PMTS working group are conducted every 6 months by Semarang AIDS Coalition. This coordination meetings discussed four main activities of PMTS Program. Data monitoring and evaluation of the meetings are done every three months by Semarang District Health Office. The task division can be used to give the same perception and avoid missing tasks. In the primary healthcare centers, all main informants also argued that they have shared tasks well and clearly in implementing the PMTS Program among MSM.

In terms of supervision, the main informants from the primary healthcare centers stated that the District Health Office have conducted supervision. They usually do field supervision or attend meetings at least twice a year. Participation from stakeholders across multiple levels will improve responsibility among the implementers to achieve the program's success.

A study conducted by Fritantus and Rukminingsih (2015) supports these findings. The researchers found that flexible procedures and good control over the program will enhance responsibility among implementers of HIV prevention policy in Surabaya. Clear regulations will ease access to HIV and AIDS services (Fritantus and Rukminingsih, 2015).

\section{Social, Economic, and Political Condition}

Subarsono (2012) asserted that the effect of the environment on policy implementation can be measured from several indicators. For example, it can be seen from how financial resources contribute to the success of program implementation, to what extent the stakeholders support the policy implementation. Even more, other effects can be measured from how the community views this policy and whether elite parties support the policy implementation or no.

Most of the main informants said that there is no financial shortage in implementing the PMTS Program among 
MSM. In primary healthcare centers, all types of HIV services are accessible and free for all Semarang citizens. Whereas, patients outside Semarang only need to pay retribution fee of IDR 5,000.00. When the patients are required to take further tests in the referral health providers, they will get financial support from the donors e.g. only for viral load and CD4 tests.

However, a study in Central Java had opposite findings. The economic condition becomes a constraint for people living with HIV and AIDS to afford healthcare services (Sagala, Suwitri and Santoso, 2013). Another study in Vietnam also claimed economic condition impedes MSM to access healthcare services since the health financing uses out of the pocket system. It means that patients will visit primary healthcare centers if only they get severe symptoms (Philbin et al., 2018).

While the political condition already has supported the PMTS Program. The political elite's support in dealing with HIV can be seen in the Regional Regulation Number 4 of 2013. The Semarang Mayor always attempted to involve the key population group in every HIV/AIDS activity to involve the key population group. However, research about HIV policy in Surakarta discovered that the political condition is not supporting, and thus it hinders the implementation of the HIV Prevention Program (Wahyuningsih, 2017). A social condition also becomes another concern. It was found that the community still disapprove and discriminate against MSM.

"There are a lot. From 1 to 10, I can say that the level of stigma and discrimination is 6 to 7 . It often occurs. A head of family passed away due to AIDS, and until now, his wife and kids have to be tested in every mobile VCT. It is a stigma, isn't it? Even though now his son has been working, he is still labeled. It was his father's first HIV even though it was not reactive and occurred years ago" (Informant from 2nd Primary Healthcare Center).

"Society tends to approve people living with HIV and AIDS. They will disregard when they know the people suffer AIDS because they are MSM, LGBT..." (Informant from District Health Office).

In a nutshell, the economic factor is not the issue for MSM to access HIV services. The elite parties have supported the PMTS Program. However, society still negatively views people living with HIV and AIDS especially those who are MSM.

Stigma and discrimination are obstacles to prevent HIV and AIDS. MSM often get discriminated from their MSM community, family, friends, and colleagues. Such disapproval and discrimination can cause MSM reluctant and afraid of coming out and accessing HIV services (Philbin et al., 2018). A study about HIV and AIDS policy in Central Java also exhibited the same findings. Social disapproval makes people living with HIV and AIDS hard to expose themselves. As a result, the HIV/AIDS Prevention Program is not well-executed (Sagala, Suwitri and Santoso, 2013).

\section{Disposition of PMTS Program}

Disposition is another essential factor in policy implementation. Disposition is described in 3 components, such as the implementer's understanding of the policy, disposition orientation, and intensity of implementer's responses towards the policy (Van Meter and Van Horn, 1975). 
The implementer's understanding about the general objectives and standards of the policy are important. If implementer respond to standars, they act on the ideas about instruction that they construct from and about these stadards. If implementers construct ideas that misconstrue policy maker's intent, then implementation failure is likely. Implementation failure in this case result not because implementers reject the reform ideas but because they understand them differently (Spillane, Reiser and Todd, 2002).

The main informants form Semarang AIDS Coalition mentioned that they have understood and practiced all four components of the PMTS Program. Moreover, the main informants from the District Health Office, primary healthcare centers and Non-Profit Organization understood not only about the program objectives, but also their roles in the program.

In supporting the policy implementation, disposition orientation toward the standards and objectives is crucial also. Implemeters may fail to execute policies faithfully because they reject the goals contained in them. Conversely, acceptance of the policy objectives can improve the success of policy implementation. According to Edwards III in Nugroho (2011), disposition has to do with willingness of the implementers to carry out a given public policy. Capacity is not enough without willingness and commitment to implement a policy (Nugroho, 2011). Those with good understanding and disposition orientation have a strong commitment to the program implementation.

Concerning disposition orientation, the main informants from Semarang AIDS Coalition worked wholeheartedly since they are responsible for their job and roles.
The District Health Office and the primary healthcare centers have a strong commitment to implement the HIV Prevention Program. Meanwhile, the authorities across sectors tend to do halfhearted jobs.

"Well, they (the authorities across sectors) just have to work somehow in a half-hearted way. But, we will completely do it since it is our job. While others might just do their job half-heartedly. They rejected the MSM community from the first time they knew them. We just do as possible as we can. We work since it is a mandate from Semarang AIDS Coalition..." (Informant from Semarang AIDS Coalition).

The implementers of the PMTS Program have good disposition orientation with a strong commitment. They have understood the program goals and objectives and been responsible for their job and roles. Commitment to the policy objectives and necessery sklills in using available resources to achive policy objectives, lead to successfull policy implementation (Khan, 2016). Despite that, the researchers found that the worst disposition orientation came from the authorities across sectors. In the very first place, they have negatively viewed the MSM community, suggesting poor disposition in implementing the PMTS Program.

The response intensity influences the program's success too. Behavioral changes are examples of responses to the policy. Implementers who negatively value the policy will deviate the program objectives. Stigma and discrimination are 
a part of negative perception of the key population group of MSM.

"Maybe lots of the stakeholders still have stigma and discrimination towards MSM. They do not agree with it. They view from the perspectives of religion, law, and morals..." (Informant from

Semarang AIDS Coalition).

In short, the disposition orientation supports the program implementation, but most of the stakeholders do not have good response intensity towards the PMTS Program among MSM. The stakeholders still consider that MSM do deviant behavior. Thus, good disposition orientation is not enough to make a program successful. It is required to have good response intensity too.

There are several limitations in this current study. First, the study only took the main informants from Semarang AIDS Coalition, Semarang Dictrict Health Office, 6 primary healthcare centers, and the Semarang City Non-Governmental Organization of the Indonesian Family Planning Association. This did not explain other information from other implementing institutions which are members of the Semarang AIDS Coalition outside the health sector.

Second, this study only involved small numbers of MSM samples, and the majority of the informants were from the same location, Semarang City. It is, therefore, less likely to generalise the results to other MSM populations in Indonesia and other similar settings. Moreover, MSM are marginalized population, and socially inactive subgroup might be less likely to reach. Therefore, the samples in this study might not fully represent the whole population of MSM in Semarang.

\section{CONCLUSION}

The PMTS Program among MSM in Semarang has not been run well. The stakeholders, implementers, and community still put stigma and discrimination on MSM, and thus these become the biggest challenges in the program implementation. Some other obstacles included unclear program standarts, limited funding and infrastructures, lack of communication and coordination among the implementers. All of these hinder the implementation of PMTS Program.

Eradication of stigma and discrimination by stakeholders across multiple levels is required. The Semarang AIDS Coalition and Semarang District Health Office as the main institutions to combat HIV must first strengthen their coordination to eliminate stigma and discrimination before forcing other stakeholders and community. All health workers in primary healthcare centers, not just limited to HIV/AIDS team, have to be introduced to ways of eradicating stigma and discrimination against MSM. Communication and coordination among the implementers should be improved under the supervision of the Semarang AIDS Coalition. Lastly, resources in terms of funding and infrastructures also need to be improved.

\section{CONFLICT OF INTEREST}

The authors state that there is no conflict of interest for this article.

\section{REFERENCES}

Dasgupta, A. N. Z. et al. (2016) 'HIV Policy and Implementation: a National Policy Review and an 
Implementation Case Study of a Rural Area of Northern Malawi.', AIDS care. Taylor \& Francis, 28(9), pp. 1097-1109. doi: 10.1080/09540121.2016.1168913.

Fritantus, Y. and Rukminingsih, N. (2015) 'Implementasi Kebijakan Penanggulangan HIV dan AIDS di Kota Surabaya', Jurnal Penelitian Administrasi Publik, 1(01), pp. 175183.

Hubaybah and Fadzlul (2014) 'Transmisi Seksual (PMTS) di Kalangan Wanita Pekerja Seks (WPS) Lokasi Gang Laler Kemayoran Jakarta Pusat Tahun 2014', Jambi Medical Journal, 4(1), pp. 39-53.

Indonesian Ministry of Health (2015) Survei Terpadu Biologis dan Perilaku (STBP) 2015. Jakarta.

Indonesian Ministry of Health (2017a) Estimasi Jumlah Populasi Kunci HIV di Indonesia Tahun 2016. Jakarta.

Indonesian Ministry of Health (2017b) Laporan Situasi Perkembangan HIVAIDS \& PIMS di Indonesia 2017. Jakarta.

Johnson, W. D., Leary, A. O. and Flores, S. A. (2018) 'Per-Partner Condom Effectiveness Against HIV for Men Who Have Sex With Men', AIDS, 32(11), pp. 1499-1505. doi: 10.1097/QAD.0000000000001832.

Joint United Nations Programme on HIV/AIDS (2018) Miles to GO: Closing Gaps, Breking Barriers, Righting Injusticer, UNAIDS. Available at: http://www.unaids.org/en/20180718_ GR2018 (Accessed: 18 June 2019).

Juhairiyah and Marlinae, L. (2016) 'Kajian Pelaksanaan Kebijakan Penanggulangan HIV / AIDS di Kabupaten Tanah Bumbu', Buletin Penelitian Sistem Kesehatan, 19(4), pp. 236-242.

Kadji, Y. (2015) Formulasi dan Implementasi Kebijakan Publik. Gorontalo: UNG Press.

Kamoru, I. and Ph, A. (2016) 'Problems and Challenges of Policy Implementation for National Development', Research on
Humanities and Social Sciences, 6(15), pp. 60-65.

Kapanda, L. et al. (2019) 'Healthcare Providers Attitudes Towards Care for Men Who Have Sex With Men ( MSM ) in Malawi', BMC Health Services Research. BMC Health Services Research, 19(1), pp. 1-9.

Khan, A. R. (2016) 'Policy Implementation: Some Aspects and Issues', Journal of Community Positive Practices, $\mathrm{XVI}(3)$, pp. 3-12. doi: 10.2307/975319.

Mahendradhata, Y. et al. (2015) 'Peran Stakeholder Kunci Dalam Kebijakan Penanggulangan dan Pencegahan HIV / AIDS Studi Kasus di Kabupaten Sorong Provinsi Papua Barat', Jurnal Kebijakan Kesehatan Indonesia, 4(2), pp. 57-64.

McRobie, E. et al. (2017) 'HIV Policy Implementation in Two Health and Demographic Surveillance Sites in Uganda: Findings from a National Policy Review, Health Facility Surveys and Key Informant Interviews', Implementation Science. BioMed Central, 12(1), p. 47. doi: 10.1186/s13012-017-0574-z.

Van Meter, D. S. and Van Horn, C. E. (1975) 'The Policy Implementation Process : A Conceptual Framework', Administration and Society, 6(4), pp. 445-488. doi: $10.1177 / 009539977500600404$.

National AIDS Coalition (2010) Pedoman Program Pencegahan HIV Melalui Transmisi Seksual. Jakarta.

National AIDS Coalition (2015) Strategi dan Rencana Aksi Nasional 20152019. Jakarta.

Nopiyani, N. M. S., Sari, K. A. K. and Sutarsa, I. N. (2016) Integrasi Penanggulangan HIV ke dalam Sistem Kesehatan Studi Kasus Program PMTS pada LSL di Kota Denpasar. Denpasar. Available at: https://www.kebijakanaidsindonesia. net/id/dokumenkebijakan/download/5-penelitianresearch/991-integrasipenanggulangan-hiv-dan-aids-kedalam-sistem-kesehatan-studi- 
kasus-program-pmts-pada-IsI-di-

kota-denpasar-unud.

Nugroho, R. (2011) Public Policy: Dinamika Kebijakan, Analisis Kebijakan, Manajemen Kebijakan. Ketiga. Jakarta: PT Elex Media Komputindo.

Otis, J. et al. (2016) 'Beyond Condoms: Risk Reduction Strategies Among Gay, Bisexual, and Other Men Who Have Sex With Men Receiving Rapid HIV Testing in Montreal, Canada', AIDS and Behavior. Springer New York LLC, 20(12), pp. 2812-2826. doi: 10.1007/s10461-016-1344-7.

Pathela, P. et al. (2013) 'HIV / AIDS HIV Incidence Among Men With and Those Without Sexually Transmitted Rectal Infections: Estimates From Matching Against an HIV Case Registry', Clicnical Infectious Diseases, 57(8), pp. 1203-1209. doi: $10.1093 / \mathrm{cid} / \mathrm{cit} 437$.

Peterman, T. A. et al. (2014) 'High Risk for HIV Following Syphilis Diagnosis Among Men in Florida, 2000 2011', Public Health Reports, 129(March-April), pp. 164-169.

Philbin, M. M. et al. (2018) 'Structural barriers to HIV prevention among men who have sex with men (MSM) in Vietnam: Diversity, stigma, and healthcare access', PLOS ONE. Edited by P. A. Newman. Public Library of Science, 13(4), pp. 1-16. doi: 10.1371/journal.pone.0195000.

Puspitaningtyas, W., Anastasia and Suryawati, D. (2012) Implementasi Program Pencegahan HIV Melalui Transmisi Seksual (PMTS) Di Kecamatan Kencong Kabupaten Jember. Jember.

Rokhmah, D. and Khoiron (2015) 'Urgensi Perubahan Implementasi Kebijakan dalam Menurunkan IMS, HIV dan AIDS pada Komunitas LSL di Kabupaten Jember', Media Kesehatan Masyarakat Indonesia, 11(4), pp. 210-217. doi: 10.30597/MKMI.V1114.524.

Sagala, A. H., Suwitri, S. and Santoso, S. (2013) 'Implementasi Kebijakan Penanggulangan Hiv Dan Aids Di
Jawa Tengah (Kajian Peraturan Daerah Provinsi Jawa Tengah Nomor 5 Tahun 2009)', Journal of Public Policy and Management Review, 2(4), pp. 116-126. doi: 10.14710/JPPMR.V2I4.3590.

Semarang AIDS Coalition (2016) SRAD Penanggulangan AIDS Kota Semarang. Semarang.

Semarang AIDS Coalition (2017) Laporan Perkembangan HIV AIDS Kota Semarang Tahun 2017. Semarang.

Solomon, M. M. et al. (2014) 'Syphilis Predicts HIV Incidence Among Men and Transgender Women Who Have Sex With Men in a Preexposure Prophylaxis Trial', Clicnical Infectious Diseases, 59(7), pp. 1020-1026. doi: 10.1093/cid/ciu450.

Spillane, J. P., Reiser, B. J. and Todd, R. (2002) 'Policy Implementation and Cognition: Reframing and Refocusing Implementation Research', Review of Educational Research, 72(3), pp. 387-431. doi: $10.3102 / 00346543072003387$.

Subarsono, A. G. (2012) Analisis Kebijakan Publik. Yogyakarta: Pustaka Pelajar.

Suharni, M. and Hersumpana (2015) Integrasi Upaya Penanggulangan HIV dan AIDS Ke Dalam Sistem Kesehatan. 1st edn. Yogyakarta: PKMK FK UGM.

Wahyuningsih, S., Novianto, W. T. and Purwadi, H. (2017) 'Implementasi Kebijakan Pencegahan dan Penanggulangan Human Immunodeficiency/Aquired Immune Deficiency Syndrome (HIV/AIDS) di Kota Surakarta', Jurnal Pasca Sarjana Hukum UNS, 5(2), pp. 178189.

Widodo, J. (2012) Analisis Kebijakan Publik Konsep dan Analisis Proses Kebijakan Publik. Pertama. Edited by S. Wahyudi, Y. Setyorini, and I. Basuki. Malang: Bayumedia Publishing. 